\title{
Injecting compassion into international wildlife law: from conservation to protection?
}

\author{
Werner Scholtz
}

\begin{abstract}
International wildlife law is concerned with the conservation of sentient species, but generally ignores the welfare of individual animals. It therefore does not reflect a recognition of the moral worth of animals and perpetuates the dichotomy between conservation and welfare. It is the primary goal of this article to ascertain how welfare concerns may be incorporated into international wildlife law in order to ensure that it takes cognizance of the moral worth of animals. The article advocates an injection of ethics, via a welfare-centric approach, into wildlife law in order to escape the dichotomy between conservation and welfare in relation to wild animals, and so to advance the progressive development of law that is conducive to wildlife protection rather than merely to its conservation.
\end{abstract}

\section{Introduction}

Something has happened to the term conservation ... it sounded rather more like an intention to conserve man than to conserve nature. ${ }^{1}$

Concern about the manner in which people should treat animals has stimulated legal and ethical discourse on the implications of the suffering of animals. The consideration of animal welfare by the Appellate Body of the World Trade Organization (WTO) in European Community - Seal Products ${ }^{2}$ and the emergence of 'global animal law' are also indicative of the increasing importance of legal and ethical questions concerning the regulation of human-animal interaction. 3 International wildlife law that deals, inter alia, with the conservation of animals generally does not concern itself with the welfare of such animals. As such, it does not reflect the recognition of the moral worth of animals and perpetuates the divide between conservation and welfare.

\footnotetext{
${ }^{1}$ M. Jacobs, 'The Spirits of Bali' (1986) 36(1) Flora Malesiana Bulletin, pp. 3920-5, at 3921.

2 European Communities - Measures Prohibiting the Importation and Marketing of Seal Products, Report of the Appellate Body, WT/DS 400/AB/R and WT/DS401/AB/R, 22 May 2014 (EC - Seal Products).

${ }^{3}$ K. Sykes, 'The Appeal to Science and the Formation of Global Animal Law' (2016) 27(2) European Journal of International Law, pp. 497-519, at 498. A. Peters, 'Symposium Foreword - Global Animal Law: What It Is and Why We Need It' (2016) 5(1) Transnational Environmental Law, pp. 9-23.
} 
This article argues that the ignorance of the moral and legal significance of animals is not satisfactory and demands progressive development. The primary goal of the article is to ascertain how welfare concerns may be incorporated into international wildlife law in order to reconcile conservation and welfare pursuant to an international wildlife law that recognizes the significance of animals.

Section 2 of the article highlights the absence of the notion of animal welfare in international wildlife law and the pressing need to address this shortcoming. The next part of the discussion (Section 3) indicates that international wildlife law follows a holistic approach to the conservation of (for example) species, whereas animal welfare law is concerned with the welfare of individual animals. It is then suggested (in Section 4) that the disconnect between conservation and welfare in international wildlife law may be explained by the near divorce of environmental law from ethics. Hence, it is imperative to inject ethics into wildlife law in order to pursue the consideration of welfare. The search for ethics must be determined by the need for the consideration of the welfare of individual animals against the background of the pursuit of conservation. This entails a potential clash between individualism (welfare) and holism (conservation). Section 5 argues for a welfare-centric ethic as this would provide a profound ethical basis for the development of welfare obligations for individual animals. These requirements inform a survey of the current legal landscape which aims to determine how to inject ethics into the law relating to wildlife. Finally, the article engages with these challenging issues in order to generate recommendations for the potential progressive development of international wildlife law through the increasing influence of animal welfare concerns.

\section{Animal significance and the ignorance of international wildlife law}

The recognition of the moral and legal significance of non-human animals has resulted in vigorous discourse 4 on the manner in which law should protect animals. The discourse is characterized by the juxtaposition of advocates of animal welfare on the one hand, and animal rights on the other.5 In terms of the 'welfare' model, human beings are morally superior to animals, which are regarded as property. ${ }^{6}$ Welfare legislation regulates the 'humane' treatment of non-human animals in order to mitigate animal suffering, while condoning the full exploitation of non-human animals in favour of human interests. Thus, welfarism entails a balancing process which weighs

\footnotetext{
${ }^{4}$ E.g., T. Regan, The Case for Animal Rights (University of California Press, 1983); P. Singer, Animal Liberation (Avon, 1975); G.L. Francione, Animals, Property, and the Law (Temple University Press, 1995); G.L. Francione, Rain Without Thunder: The Ideology of the Animal Rights Movement (Temple University Press, 1996); G.L. Francione \& R. Garner, The Animal Rights Debate: Abolition or Regulation? (Columbia University Press, 2010); C.R. Sunstein\&M.C. Nussbaum (eds), Animal Rights: Current Debates and New Directions (Oxford University Press, 2004); S. Donaldson \& W. Kymlicka, Zoopolis: A Political Theory of Animal Rights (Oxford University Press, 2011).

${ }^{5}$ Between these opposing positions other perspectives are to be found, such as enlightened welfarism, which suggests that although equal consideration should not necessarily be accorded to animals, their interests should weigh more than they do at present. This approach accommodates responsible experimentation on animals, for instance.

${ }^{6}$ Francione (1995), n. 4 above, p. 6. It is not the intention of the author to provide an account of this position.
} 
the interests of non-human animals against those of humans in order to determine whether animal pain and suffering is 'necessary' or 'justified'.7 Scholars who oppose welfarism favour granting rights to animals in order to give recognition to their inherent value. ${ }^{8}$ For example, Anne Peters has recently argued for the utility of a (modified) transposition of the international human rights framework to provide animals with some form of subjective rights in order to further their interests. 9

International wildlife law does not reflect the settled moral and legal significance ${ }^{10}$ of human-animal interaction. It is concerned primarily with the pursuit of the conservation of wildlife ${ }^{11}$ and largely ignores the fact that it regulates sentient beings, ${ }^{12}$ which are capable of experiencing pain and suffering. A regulatory distinction is further made between the welfare of wildlife and domestic animals. 13 The majority of jurisdictions possess national law that regulates the welfare of domestic animals, whereas wild animal welfare law is almost non-existent.14 In some instances welfare law is incidental to conservation measures, such as the transport of wildlife. ${ }^{15}$ This leaves wildlife generally unprotected from cruelty. As one commentator aptly remarks:

\footnotetext{
${ }^{7}$ Ibid., p. 7.

${ }^{8}$ A section of the animal rights movement focuses on the ultimate goal of the abolition of animal usage: T. Regan, Defending Animal Rights (University of Illinois Press, 2001), p. 3. However, see R. Garner, 'A Defense of Broad Animal Protectionism', in Francione \& Garner, n. 4 above, pp. 101-78, and Francione (1995), n. 4 above, p. 261. Donaldson and Kymlicka are of the opinion that, although the discourse of animal rights theory is well established in academic circles, 'it has virtually no resonance amongst the general public': Donaldson \& Kymlicka, n. 4 above, pp. 4-5.

${ }^{9}$ A. Peters, 'Liberté, Égalité, Animalité: Human-Animal Comparisons in Law' (2016) 5(1) Transnational Environmental Law, pp. 2553. Certain proposals for the adoption of international instruments that embody a rights approach include the Universal Declaration of Animal Rights (UDAR), Paris (France), 15 Oct. 1978, available at: https://constitutii.files.wordpress.com/2016/06/file-id-607.pdf.

${ }^{10}$ Francione \& Garnier, n. 4 above, pp. ix-xii.

${ }^{11}$ K. Sykes, 'Nations Like unto Yourselves: An Inquiry into the Status of a General Principle of International Law on Animal Welfare' (2011) 49 Canadian Yearbook of International Law, pp. 3-49, at 4.

${ }^{12}$ Animals and their treatment matter because they are sentient beings, which mean that they are perpetually aware: G.L. Francione, 'The Abolition of Animal Exploitation', in Francione \& Garner, n. 4 above, pp. 1-101, at 15. European Union (EU) law recognizes animals as sentient beings: Art. 13 of the Treaty on the Functioning of the European Union (TFEU), Lisbon (Portugal), 13 Dec. 2007 , in force 1 Dec. 2009, [2010] OJ C 83/47, available at: http://eur-lex.europa.eu/LexUriServ/LexUriServ. do?uri=OJ:C:2012:326:FULL:EN:PDF. For a discussion of the implications of Art. 13 TFEU on EU law, see R. Ludwig \& R. O'Gorman, 'A Cock and Bull Story? Problems with the Protection of Animal Welfare in EU Law and Some Proposed Solutions' (2008) 20(3) Journal of Environmental Law, pp. 363-90, at 379-82.

13 G.B. Spark, 'Protecting Wild Animals from Unnecessary Suffering' (2014) 26(3) Journal of Environmental Law, pp. 473-94; G. Wandesforde-Smith \& L.A. Hart, 'Exploring the Borderlands between Wild and Non-Wild Animals: Wildlife Law and Policy in Transition' (2015) 18(4) Journal of International Wildlife Law and Policy, pp. 269-75. The distinction is not always clear as wildlife may be owned by people and kept in captivity. An individual may claim ownership of a wild animal through possession, control, domestication or confinement, or through killing the animal: J.E. Schaffner,An Introduction to Animals and the Law (Palgrave Macmillan, 2011), p. 22. The validity of the distinction between non-wild/wild animals for the purposes of welfare regulation is questioned.

${ }^{14}$ For a comprehensive comparative overview of domestic jurisdiction that regulates animal welfare, see B.A. Wagman \& M. Liebman, A Worldview of Animal Law (Carolina Academic Press, 2011), pp. 28-47, Ch 5 (pp. 255-78) of which discusses constitutional provisions of relevance. See also M. Michel, ‘Tierschutzgesetzgebung im Rechtsvergleich: Konzepte und Entwicklungstendenzen', in M. Michel, D. Kühne \& J. Hänni (eds), Animal Law - Tier und Recht (Dike, 2012), pp. 593-625.

15 The most cited example is the Convention on International Trade in Endangered Species of Wild Fauna and Flora (CITES), Washington, DC (United States (US)), 3 Mar. 1973, in force 1 July 1975, available at: https://www.cites.org. Art. VIII(3) CITES, e.g., obliges parties to ensure that specimens in transit are properly cared for so as to minimize the risk of injury, damage to health or cruel treatment. It is clear that the minimization of the risk of injury and damage to health relates to the objective of conservation. Similar requirements are included in $\operatorname{Arts} \operatorname{III}(2)(c), \operatorname{III}(4)(b), \operatorname{IV}(2)(c), \operatorname{IV}(5)(b), \operatorname{IV}(6)(b), V(2)(b)$ and VII(7)(c) CITES. For a comprehensive
} 
Wild animal welfare law is sparse, bordering on the non-existent at the international level. It is clear that the welfare of animals living in the wild usually receives far less attention than the welfare of agricultural or other domestic animals. Often this area of the law derives unobtrusively, incidentally, or even accidentally from measures designed to conserve species. ${ }^{16}$

However, the entanglement of animal interests with transnational issues - such as global environmental protection, the transboundary movement of species (irrespective of territorial borders), and the potential trade implications of animal welfare measures in the context of the comprehensive trade regime ${ }^{17}$ - indicate that animal welfare has implications for international wildlife law.

Thus, the status quo is not satisfactory. The ignorance on the part of international law of the sentience of non-human animals does not accord with the 'emerging recognition in international law that animals have some significance in themselves and as individual beings, not merely as a means to human ends and not just as members of species'. ${ }^{18}$ This emerging recognition should be viewed in the context of the current age of globalization, which has resulted in the globalization of animal welfare and the need for a global reaction to animal welfare issues ${ }^{19}$ in order to respond to the absence of an international animal welfare regime. ${ }^{20}$ Accordingly, Bowman aptly remarks that it is unquestionably legitimate, and arguably compulsory (under international law), to afford (animal welfare) due consideration in the development of policy regarding the exploitation of wild fauna of all descriptions'. ${ }^{21}$ Bowman, Davies and Redgwell, in their authoritative exposition on wildlife and welfare in international law, suggest that the intrinsic value of wildlife ${ }^{22}$ means that 'any sound ethical policy should additionally have regard to the extent to which individual organisms are permitted to flourish in accordance with their biological nature', and thus the expectation exists that a corpus of rules should have emerged for the protection of individual wildlife specimens based on the recognition of their moral concern on their own account. ${ }^{23}$ However, the authors affirm that international obligations in respect

discussion, see M. Bowman, 'Conflict or Compatibility? The Trade, Conservation and Animal Welfare Dimensions of CITES' (1998) 1(1) Journal of International Wildlife Law and Policy, pp. 9-63, at 9, 21-5.

${ }^{16}$ S.R. Harrop, 'The Dynamics of Wild Animal Welfare Law' (1997) 9(2) Journal of Environmental Law, pp. 287-302, at 287.

17 T.G. Kelch, Globalization and Animal Law: Comparative Law, International Law and International Trade (Kluwer Law International, 2011), pp. 239-70; K. Sykes, 'Sealing Animal Welfare into GATT Exceptions: The International Dimensions of Animal Welfare in WTO Disputes' (2014) 13(3) World Trade Review, pp. 471-98.

${ }^{18}$ Sykes, n. 11 above, p. 10.

${ }^{19}$ Peters, n. 3 above.

${ }^{20}$ M. Park \& P. Singer, 'The Globalization of Animal Welfare: More Food Does Not Require More Suffering' (2012) 91(Mar./Apr.) Foreign Affairs, pp. 122-33.

${ }^{21}$ M. Bowman, "Normalizing" the International Convention for the Regulation of Whaling' (2008) 29(3) Michigan Journal of International Law, pp. 293-499, at 459.

22 The intrinsic value of biological resources is recognized in the Preamble to the Convention on Biological Diversity (CBD), Rio de Janeiro (Brazil), 5 Jun. 1992, in force 29 Dec. 1993, available at: https://www.cbd.int/doc/legal/cbd-en.pdf.

${ }^{23}$ M. Bowman, P. Davies \& C. Redgwell, Lyster's International Wildlife Law (Cambridge University

Press, 2010), p. 672. 
of animal welfare issues remain scarce and have been addressed mostly at the national level. A possible reason for the scarcity of international law in this regard may be found in the political difficulty of regulating animal welfare through international law and achieving international consensus on a matter which is characterized by cultural differences. ${ }^{24}$

Pressing circumstances caused by the negative consequences of anthropogenic activities on the environment, such as climate change, may continue to result in a shrinking of the 'wild' as a result of habitat loss. The loss and fragmentation of habitat may necessitate a constriction of species into a more geographically limited and controlled environment, which may lead to more intrusive ex situ conservation methods, as well as the imposition of control measures over wild species similar to the manner in which this occurs in agriculture. 25 The surge in human-animal interaction 'may increase the need to inject compassion into our environmental law and policy'. ${ }^{26}$ It must be borne in mind that the relationship between human beings and non-human animals, in particular wildlife, is characterized by alienation. ${ }^{27}$ The consequence of this social distance is a systemic preference for human interests over the interests of animals. Hence, it is important to ensure a decrease in the social distance ${ }^{28}$ between people and animals through the inclusion of environmental ethics in international wildlife law, to cater for the changing interaction between people and animals. ${ }^{29}$

\section{A narrative of dualisms}

The call for the inclusion of environmental ethics in international wildlife law must be understood in light of the separation between animal welfare law and international wildlife law. Conservation is the primary focus of international wildlife law. Conservation instruments avoid a rigid definition of this concept, but it seems to embrace notions such as 'the preservation, maintenance, sustainable utilization, restoration, and enhancement of a natural resource or the environment'.30 Conservation is informed by scientific and economic assumptions on the basis of an anthropocentric concern, whereas animal welfare is more concerned with ethical assumptions. ${ }^{31}$ Conservation follows a holistic approach as it pertains to species ${ }^{2}$ or

\footnotetext{
${ }^{24}$ Harrop, n. 16 above, p. 289.

25 S.R. Harrop, 'Climate Change, Conservation and the Place for Wild Animal Welfare in International Law' (2011) 23(3) Journal of Environmental Law, pp. 441-62, at 450.

${ }^{26}$ Ibid., p. 442.

${ }^{27}$ L.C. Becker, 'The Priority of Human Interests', in T. Regan \& P. Singer (eds), Animal Rights and Human Obligations (Prentice Hall, 1989), pp. 87-94, at 92.

${ }^{28}$ For a narrative of the history of the interaction between humans and animals: Kelch, n. 17 above, pp. 1-18; D. Nibert, Animal Rights/Human Rights (Rowman and Littlefield, 2002), pp. 101-41.

${ }^{29}$ Yang considers this as one of the distinctive features of environmental ethics: T. Yang, 'Towards an Egalitarian Global Environmental Ethics', in H. ten Have (ed.), Environmental Ethics and International Policy (UNESCO, 2006), pp. 23-45, at 24.

30 This is in accordance with the definition of the World Commission on Environment and Development Experts Group on Environmental Law: P. Birnie, A. Boyle \& C. Redgwell, International Law and the Environment (Oxford, 2009$)$, p. 593.

31 S.R. Harrop, 'From Cartel to Conservation and on to Compassion: Animal Welfare and the International Whaling Commission' (2003) 6(1-2) Journal of International Wildlife Law and Policy, pp. 79-104, at 80-1.
} 
species types (such as marine living resources),33 habitat/biomes (such as wetlands), 34 and/or biodiversity 35 and ecosystems. ${ }^{36}$

Animal welfare law, on the other hand, involves the humane treatment of animals or the prevention of unnecessary pain (in relation to individual animals).37 'Humane' suggests a compassion that enables empathy with the pain of others. ${ }^{8}$ Science plays an important complementary role in relation to animal welfare law as scientific research provides profound insights concerning various matters pertaining to animals, such as the determination of the extent of suffering that an animal experiences in relation to a specific intrusion. 39 Moral assumptions accordingly determine the moral duty to prevent suffering. The input of science in relation to the international regulation of the trapping of wild animals provides a suitable example of the interplay between science and ethics in this regard. A controversial issue in relation to the 'killing trap' is the time that it takes for the suffering of an animal to cease from the moment the trap is triggered until the loss of consciousness or death. Science is subjected to moral judgments where the question concerning the accepted time until death arises. 40

The distinction between ethical and scientific arguments is not always clear, however, and convergence occurs. The policy and politics surrounding the whaling regime also present interesting examples of the convergence between conservation (science) and welfare (ethics). ${ }^{41}$ For instance, the regulation of the type of harpoon to be used in the killing process seems to respond to concerns for whale welfare, as is evident in the debates

32 Art. I(a) CITES, n. 15 above, defines species to include 'any species, subspecies or geographically separate population thereof'.

33 The whaling regime presents an example: see W. Scholtz, 'Killing Them Softly? Animal Welfare and the Inhumanity of Whale Killing: From Conservation to Compassion' (forthcoming 2017) 20 Journal of International Wildlife Law and Policy.

${ }^{34}$ Convention on Wetlands of International Importance especially as Waterfowl Habitat (Ramsar Convention), Ramsar (Iran), 2 Feb. 1971, in force 21 Dec. 1975, available at: http://www.ramsar.org.

35 Art. 1 CBD, n. 22 above, includes the conservation of biological diversity and the sustainable use of its components as objectives of the instrument. Art. 2 CBD defines biological diversity as 'the variability among living organisms from all sources including, inter alia, terrestrial, marine and other aquatic ecosystems and the ecological complexes of which they are part; this includes diversity within species, between species and of ecosystems.' Thus, biodiversity relates to the diversity of ecosystems (or habitat), species and genetic diversity.

${ }^{36}$ Art. 2 CBD, n. 22 above, defines an ecosystem as 'a dynamic complex of plant, animal and microorganism communities and their non-living environment interacting as a functional unit'. Art. 8 CBDplaces an emphasis on in situ conservation, which it defines as 'the conservation of ecosystems and natural habitats and the maintenance and recovery of viable populations of species in their natural surroundings'.

${ }^{37}$ A precise universal definition of animal welfare does not exist. Some commentators restrict the notion to physical well-being, whereas others focus on the emotional response of animals. For a discussion, see R.P. Haynes, Animal Welfare: Competing Conceptions and their Ethical Implications (Springer, 2010), p. 107. The Agreement on International Humane Trapping Standards between the European Union, Canada and the Russian Federation (1998, in force July 2008, available at: http://www.face.eu/ international-agreements/aihts), Annex I, Pt I, para. 1.3.1 affirms that the '[w] elfare of animals is indicated by measures of the extent of ease or difficulty in their coping with the environment and the extent of failure to cope with their environment'. Although welfare can vary widely, the term 'humane' is used only for those trapping methods where the welfare of the animals concerned is contained at a sufficient level.

${ }^{38}$ A. Gillespie, 'Humane Killing: A Recognition of Universal Common Sense in International Law' (2003) 6(1) Journal of International Wildlife Law and Policy, pp. 1-29, at 4.

${ }^{39}$ Sykes, n. 3 above, p. 505.

${ }^{40}$ S.R. Harrop, 'The International Regulation of Animal Welfare and Conservation Issues through Standards Dealing with the Trapping of Wild Animals' (2000) 12(3) Journal of Environmental Law, pp. 333-60, at 350.

${ }^{41}$ For a comprehensive overview, see A. Gillespie, Whaling Diplomacy: Defining Issues in International Environmental Law (Edward Elgar, 2005), pp. 148-77, and M. Fitzmaurice, Whaling and International Law (Cambridge University Press, 2015 ), pp. $153-83$. 
preceding the acceptance thereof, and not in relation to scientific evidence linked to conservation. An almost global opposition to whaling often includes anti-whaling arguments which are based on a mixture of conservation and welfare grounds.

Animal welfare considerations are often incidental to conservation measures and, in some instances, conservation and welfare interests converge. $4^{2}$ However, those interests frequently conflict. The best illustration of conflicting interests may be found in the culling of wildlife for conservation purposes, which raises welfare issues. It is clear that the incidental convergence of interests will not always result in the promotion of the welfare of wildlife. One of the major reasons for this is that incidental welfare measures will relate merely to species and not to individual animals.

\section{Death of ethics and resurrection through welfare}

The dichotomy between conservation and welfare may be explained by what Purdy refers to as the 'near divorce of environmental law from ethics in the last few decades'.43 Purdy's viewpoint does not negate the existence of environmental ethics or its influence on environmental law. Rather, he bemoans the absence of the 'codevelopment of environmental law and ethical consciousness', which could recognize 'the moral importance of natural entities, living and otherwise, for their own sake'. 44 The disconnect between ethics and environmental law is not inevitable but has been fostered 45 by 'the changing context of events'. Hence, it should be possible to insert environmental values in law in an innovative manner in response to changing circumstances. In the 1970s, Tribe identified and analyzed the inadequacies of the homocentric foundation of environmental law, which is focused on the satisfaction of individual human wants, in order to generate proposals for an alternative rationale beyond human wants. 46 This process must be initiated by 'encouraging the elaboration of perceived obligations to plant and animal life and to objects of beauty in terms that do not falsify such perceptions from the very beginning by insistent "reference to human interests"'.47 In this regard, Tribe supports the proposal of Stone, who advocated that nature must be awarded rights, which could be enforced by appointed (human) guardians. 48 This could result in an approach where natural

\footnotetext{
${ }^{42}$ Harrop, n. 16 above, p. 287. The incidental derivation of welfare measures from conservation objectives may be illustrated by reference to the Convention on the Conservation of European Wildlife and Natural Habitats (Bern Convention), Bern (Switzerland), 19 Sept. 1979, in force 1 June 1982, available at: http://www.coe.int/en/web/bern-convention. Art. 8 is concerned with the reduction of the killing of endangered or sensitive species through indiscriminate methods of capture of animals. The incidental welfare consequence of this provision is that it may alleviate suffering, as indiscriminate methods can result in suffering, in particular to non-target animals.

43 J. Purdy, 'Our Place in the World: A New Relationship for Environmental Ethics and Law' (2013) 62(4) Duke Law Journal, pp. 857932, at 862 .

${ }^{44}$ Ibid., p. 860.

${ }^{45}$ Ibid., p. 862.

${ }^{46}$ L.H. Tribe, 'Ways Not to Think About Plastic Trees: New Foundations for Environmental Law' (1974) 83(7) The Yale Law Journal, pp. 1315-48.

${ }^{47}$ Ibid., p. 1341.

${ }^{48}$ Cf. C.D. Stone, Should Trees Have Standing? And Other Essays on Law, Morals and the Environment (Oceana, 1996$)$, pp. 1-47.
} 
objects are entities worth moral consideration in their own right and are not of relevance only by virtue of the health and well-being of human beings. 49

The 'rights for nature' approach has resulted in a plethora of scholarly discourse.50 The main criticism of the 'rights for nature' approach centres on the argument that most non-sentient natural objects do not have moral claims. In essence, the moral worthiness of non-sentient objects, such as mountains and rivers, is not a settled matter in ethical discourse. This is also evident from Tribe's recognition that the social distance in relation to animals is less than that in relation to natural objects, and that protecting animals from torture based on a desire to be free from pain and personal suffering 'seems less jarring conceptually' than protecting a forest on the basis of an inherent right to life. ${ }^{11}$ Regan remarks that inherent value is an attribute of those who are the 'experiencing subjects of life' and '[w]hether it belongs to others - to rocks and rivers, trees and glaciers, for example - we do not know and may never know'.52 However, he points out that the sentience of most non-human animals has been established and serves as a point of departure for the existence of the moral claims of this group. Thus, the sentience of and, accordingly, the inherent value of animals and their position in international wildlife law offers the potential for ethical and legal development. In this vein, the established sentience of non-human animals and their moral worth provides an 'easier' avenue to pursue non-human interests in law and a departure from human dominance. The pursuit of animal welfare in international wildlife law may therefore provide an opportunity to inject ethics into law, which may erode its anthropocentric nature. Animal welfare should be pursued on the basis of solidarity53 with sentient beings. This will facilitate a decrease in social distance and facilitate the expansion of obligations to sentient beings for their own sake. This proposed form of solidarity is based on the shared capacity of sentient beings to experience pain and suffering, as this is the most obvious indication of the involvement of animals in the struggle for life and well-being. 54

The main impediment to the inclusion of animal welfare in wildlife law remains the anthropocentric nature of law.55 The issue of the welfare of animals in the context of international wildlife law requires an examination of the human-animal relationship against the broader background of the relationship between people and the environment. In this regard, scholars who are critical of anthropocentrism have advocated in favour of biocentrism and/or ecocentrism in order to escape from an

\footnotetext{
${ }^{49}$ Cf. A. Brennan, 'The Moral Standing of Natural Objects', in A. Brennan (ed.), The Ethics of the Environment (Dartmouth, 1995), pp. 35-56.

${ }^{50}$ See, e.g., the contributions in the special edition of (2012) Journal of Human Rights and the Environment, pp. 1-120.

51 Tribe, n. 46 above, p. 1343. Stone indicates that he limits himself to a discussion of non-animal objects, but alludes to the appropriateness of his analysis to advancing animal rights, inter alia: Stone, n. 48 above, p. 9.

${ }^{52}$ Becker, n. 27 above, p. 92.

${ }^{53}$ Purdy, n. 43 above, p. 894.

${ }^{54}$ G. Steiner, Animals and the Moral Community: Mental Life, Moral Status and Kinship (Columbia University Press, 2008 ), p. 126.

55 J. Nouët, 'Origins of the Universal Declaration of Animal Rights', in G. Chapouthier \& J. Nouët (eds), The Universal Declaration of Animal Rights: Comments and Intentions (Ligue Française des Droits de l’Animal, 1998), pp. 9-16, at 13.
} 
approach that focuses on the instrumental value that nature has for human beings. 56 However, Purdy is critical of the utilization of value theory in relation to environmental law and ethics, as it does not assist in the creation 57 or implementation 58 of environmental law.59

This article argues that the expansion of our legal and moral obligations to other sentient animals requires a movement beyond mere anthropocentrism ${ }^{60}$ towards a 'welfare-centric ethic', rather than a shift towards a 'biocentric' or 'ecocentric' position, as often advocated by opponents of anthropocentrism. ${ }^{61}$ The welfare-centric ethic is based on a 'welfarist' understanding of the interests of sentient individual animals. ${ }^{62}$

This approach requires an individual to have the capacity for 'conscious experience' in order to have interests. Interests are perceived as components of well-being. Well-being is concerned with how life goes for the individual leading it. Non-conscious objects, such as plants or rivers, are excluded from the class of interest holders by virtue of the fact that, although events can impact on their condition, 'nothing can make life better or worse for those objects themselves'.63 Well-being is a requirement for the possession of moral status and is a point of departure for any moral obligation to strive for the improvement of the well-being of individual animals. ${ }^{64}$ Thus, wildlife, such as individual elephants and whales, are sentient beings with an interest to be free from pain and suffering inflicted by human beings through, for example, hunting, and they have the capacity to experience the benefit of being free from pain and suffering.

The exclusion of non-conscious entities could be criticized as it entails a weak environmental ethic, which does not accommodate a holistic approach to the environment. ${ }^{65}$ The welfare-centric ethic does, however, take cognizance of holism without ignoring the interests of individualism via a clear recognition of the

\footnotetext{
${ }^{56}$ Purdy, n. 43 above, p. 872. For a discussion of the different approaches in environmental ethics, see Yang, n. 29 above, pp. $28-33$.

57 The determination of value is inseparable from human experience, and it is therefore impossible to depart from the anthropocentric approach: W. Scholtz, 'Animal Culling: A Sustainable Approach or Anthropocentric Atrocity? Issues of Biodiversity and Custodial Sovereignty' (2005) 2(2) Macquarie Journal of International and Comparative Environmental Law, pp. 9-30.

${ }^{58}$ According to Purdy (n. 43 above, p. 874) the focus on value theory fails to guide action in terms of the operation of legislation.

${ }^{59}$ Ibid.

${ }^{60}$ It would be more correct to refer to weak anthropocentrism: C. Redgwell, 'Life, the Universe and Everything: A Critique of Anthropocentric Rights', in A.E. Boyle \& M.R. Anderson (eds), Human Rights Approaches to Environmental Protection (Oxford University Press, 1996), pp. 71-87, at 73.

${ }^{61}$ A. Cochrane, Animal Rights Without Liberation: Applied Ethics and Human Obligations (Columbia University Press, 2012 ), p. 156.

${ }^{62}$ Francione \& Garnier, n. 4 above, p. i; see also G. Chartier, 'Natural Law and Animal Rights' (2010) 23(1) Canadian Journal of Law and Jurisprudence, pp. 33-46. For a defence of the position that nonsentient beings cannot possess interests and moral status, see Cochrane, ibid., p. 157.

${ }^{63}$ Cochrane, ibid., p. 158. Cochrane analyzes the proposal that non-conscious entities may also have interests and defends the welfarist understanding of interests by stating that '[i]t is true that not all interests are tied to conscious desires ... But that does not undermine the point that the capacity for conscious experience is necessary for the possession of interests': ibid., p. 159.

${ }^{64}$ Ibid., p. 160.

${ }^{65}$ Environmentalists favour holism rather than an exclusive concern with the plight of individual entities of the biotic community. This is evident from the much-quoted remark of Leopold: 'A thing is right when it tends to preserve the integrity, stability, and beauty of the biotic community. It is wrong when it tends to do otherwise': A. Leopold, A Sand County Almanac (Oxford University Press, 1949, reprinted 2001), p. 189.
} 
interlinkage between the well-being of humans, other sentient beings, and habitat. The well-being of sentient beings is absolutely dependent on the health of nonconscious nature'. ${ }^{66}$ This approach accords with the provision of a human right to a healthy environment, which may impose environmental obligations on human beings. Section 24 of the Constitution of the Republic of South Africa of 1996, for example, establishes an anthropocentric environmental right which focuses on the well-being of people, but which recognizes the interdependence between human well-being and the condition of the environment. ${ }^{67}$

The welfare-centric ethic moves beyond the human rights-focused approach as it also takes into consideration the well-being of animals in the formulation of environmental obligations and, as such, offers protection to non-sentient components of the environment based on their contribution to the well-being of all sentient individuals. ${ }^{68}$ For example, anthropogenic environmental degradation, particularly climate change, constitutes a major threat to whale welfare as a result of the impact that human activities have on the habitat of whales and the related suffering and death that this causes. ${ }^{69}$ Several international instruments affirm the importance of habitat protection in the promotion of conservation. Such protection is concerned with indirect threats to species, such as those arising from habitat destruction or pollution. The 1979 Convention on the Conservation of Migratory Species of Wild Animals (CMS Convention), 70 which focuses on international cooperation in relation to 'migratory species which have an unfavourable conservation status', is exemplary of this approach. ${ }^{11}$ It defines 'conservation status' as 'the sum of influences acting on the migratory species which may affect its long-term distribution and abundance'. ${ }^{2}$ The CMS Convention continues to list conditions which may constitute an unfavourable conservation status.73 It is especially interesting to note that the third condition states that 'there is not, and will not be in the foreseeable future, a sufficient habitat to maintain the population of the migratory species on a long-term basis'. ${ }^{74}$

\footnotetext{
${ }^{66}$ Cochrane, n. 61 above, p. 162.

${ }^{67}$ W. Scholtz, 'The Anthropocentric Approach to Sustainable Development in the National Environmental Management Act and the Constitution of South Africa' (2005) 1 Journal of South African Law, pp. 69-85.

${ }^{68}$ Cochrane recognizes the limits of this approach. A necessary link between habitat destruction and animal suffering does not exist per se and this implies that it will be difficult to establish obligations to prevent environmental degradation if it does not harm the well-being of animals: Cochrane, n. 61 above, p. 162. In general, however, habitat destruction will impact negatively on sentient beings (including animals), which is a good reason for preventing its destruction.

${ }^{69}$ Gillespie, n. 41 above, p. 45.

${ }^{70}$ Bonn (Germany), 23 June 1979, in force 1 Nov. 1983, available at: http://www.cms.int/en/node/3916.

${ }^{71}$ E.g., CMS Convention, ibid., Art. IV(1).

${ }^{72}$ Ibid., Art. I(1)(b).

${ }^{73}$ Ibid., Art. I(1)(c) read with (d). The conservation status of a species will be unfavourable when the following conditions are not met: (i) population dynamics data indicate that the migratory species is maintaining itself on a long-term basis as a viable component of its ecosystems; (ii) the range of the migratory species is neither currently being reduced, nor is likely to be reduced, on a long-term basis; (iii) there is, and will be in the foreseeable future, sufficient habitat to maintain the population of the migratory species on a long-term basis; and (iv) the distribution and abundance of the migratory species approach historic coverage and levels to the extent that potentially suitable ecosystems exist and to the extent consistent with wise wildlife management.

${ }^{74}$ See also the Ramsar Convention, n. 34 above, and the Bern Convention, n. 42 above.
} 
In the age of the Anthropocene, the recognition of human beings as a geophysical force implicitly confirms that people continue to deprive species of their life-sustaining habitats or reduce the capacity of habitats to support species in an effective manner.75 Not only does the increase in human activity result in the loss of or modification of species, but it also results in the suffering of non-human animals 'through displacement, stress, starvation and reduced security'. ${ }^{6}$ Hence, human-induced environmental degradation results in a decrease in the well-being of human beings and wildlife as a result of habitat degradation. Habitat destruction raises simultaneous conservation and welfare concerns and constitutes a common ground for conservationists and welfarists. The proposed link between welfare and conservation affirms the importance of having regard for the well-being of other sentient individuals in the (holistic) context of the well-being of the non-sentient components of habitat. This implicit link between conservation and welfare may provide an explanation for the ancillary manner in which conservation measures in some instances cater for welfare considerations.

Hence, the welfare-centric ethic does not get caught up in the conceptual problems presented by the holism-individualism value dichotomy. ${ }^{77}$ The approach does recognize that sentient beings form part of a complex biosphere of intertwined organisms, but also acknowledges the value of the individual. The exclusive focus on holism does not take satisfactory cognizance of the changed role of human beings in the Anthropocene, 78 which have become a geophysical force capable, inter alia, of causing climate change. 79 Human beings are indeed intertwined with the other organisms in the biosphere, but human beings are also a force that must be viewed differently from other entities. This statement does not accord human beings dominance, but rather draws attention to their destructive nature. Conversely, an overt focus on individualism might ignore the interwoven nature of the biosphere and, furthermore, serve as justification for interventions in nature to address any form of suffering of wildlife. An example of such an intervention is the proposal to apply genetic engineering to exterminate predation. ${ }^{80}$ It is imperative to recall that wild animals live in a designated wilderness, independent of human provision, and humans as moral agents are not causally responsible for the predation of wild animals, which are not considered to be moral agents. ${ }^{81}$ Interventions in nature to address predation may have unforeseen negative consequences in the natural world. ${ }^{82}$

\footnotetext{
75 P.C. Paquet \& C.T. Darimont, 'Wildlife Conservation and Animal Welfare: Two Sides of the Same Coin?' (2010) 19(2) Animal Welfare, pp. 177-90, at 177.

76 Ibid.

${ }^{77}$ Purdy, n. 43 above, p. 874.

${ }^{78}$ D. Vidas, J. Zalasiewicz \& M. Williams, 'What Is the Anthropocene - and Why Is It Relevant for International Law?' (2014) 25(1) Yearbook of International Environmental Law, pp. 3-23.

${ }^{79}$ D. Chakrabarty, 'The Climate of History: Four Theses' (2009) 35(2) Critical Inquiry, pp. 197-222, at 198.

${ }^{80}$ G. Easterbrook, A Moment on the Earth: The Coming Age of Environmental Optimism (Viking, 1996), p. 431.

${ }^{81}$ C. Palmer, 'The Moral Relevance of the Distinction between Domesticated and Wild Animals', in C.T.L. Beauchamp \& R.G. Frey (eds), The Oxford Handbook of Animal Ethics (Oxford University Press, 2011), pp. 701-25, at 713.

82 J.B. Callicott, 'The Philosophical Value of Wildlife', in S.J. Armstrong \& R.G. Botzler (eds), The Animal Ethics Reader (Routledge, 2008), pp. 439-43, at 441.
} 
The significance of the welfare-centric ethic is that it provides a profound ethical basis for the development of welfare obligations for individual animals in order to promote the well-being of wildlife. The formulation of the aforesaid obligations also takes cognizance of, for instance, habitat as it is conducive to the well-being of individual sentient beings. As such, it caters for individual animals within a holistic context and does not fall prey to recourse to either anthropocentrism, biocentrism, or ecocentrism.

In the author's opinion, Feminist Care Theory (FCT) ${ }^{83}$ could shape the development of legal welfare obligations on the basis of the welfare-centric approach. ${ }^{84}$ The recent article by Thomas Kelch in this journal offers a valuable analysis of the manner in which a variant of FCT may be used to derive principles which can be used to address animal suffering. The source of the ethical principles of FCT is 'caring', which is grounded in the emotions of compassion, sympathy or empathy. In accordance with this approach, caring is focused on the suffering of others in a seamless web of relationships, which includes animal life. This web of relationships is non-hierarchical, but recognizes differences between forms of life. 85 This is in line with the fact that people are part of the biosphere, share with animals a common relationship with the Earth and dwell alongside animals as one of the species confronted with pain and suffering. Of course, FCT does so in full recognition of the differences between species. Kelch identifies a logical process which bridges the emotive response of caring with the practical establishment of legal policy or rules to end suffering. ${ }^{86}$ Firstly, a stimulus (the suffering of wildlife) initiates the caring set of emotions. Secondly, the observer (a 'hypothetical emotionally sound human') experiences caring in relation to the stimulus. Thirdly, caring is applied to the stimulus. Fourthly, a derivation of a moral principle or principles from the emotive and cognitive response to the stimulus takes place. Fifthly, a means to end the suffering is discovered which may entail the translation of a principle of general application into a proposed legal rule. Thus, the suffering, or potential suffering, of an individual animal or a group (or groups) of animals arouses compassion and the impulse to care and so to end the suffering. The suffering may be alleviated through the formulation of principles and, ultimately, legal rules to address the welfare of animals. FCT may therefore be useful to guide a process towards the development of legal rules and policy that would address wildlife welfare on the basis of compassion, in accordance with the welfare-centric ethic.

In summary, the welfare-centric ethic is suitable to facilitate the convergence of opposing interests represented by the divide between conservation and welfare in

\footnotetext{
${ }^{83}$ T.G. Kelch, 'Towards Universal Principles for Global Animal Advocacy' (2016) 5(1) Transnational Environmental Law, pp. 81-111. An important criticism of this feminist ethic is that it may be too vague to guide concrete decision making in relation to animals. For a discussion of feminism and animal rights: J. Donovan, 'Animal Rights and Feminist Theory' (1990) 15(2) Signs, pp. 350-75.

${ }^{84}$ For a discussion of the application of FCT to wild animals: G. Clement 'The Ethic of Care and the Problem of Wild Animals', in Armstrong \& Botzler (eds), n. 82 above, pp. 444-50.

${ }^{85}$ Kelch, n. 83 above, p. 93.

${ }^{86}$ Ibid., p. 101.
} 
wildlife law by virtue of the recognition of the link between the well-being of human beings, other sentient beings, and habitat. However, habitat loss is not always a sufficient nexus to ensure that conservation takes cognizance of the individual welfare of animals. Not all instances of habitat destruction will result in welfare concerns. It is therefore important to ensure that the convergence of conservation and welfare is guided by FCT, which is concerned with caring. Wildlife conservation should therefore not occur in isolation from the welfare concerns of animals, as well as the well-being of the biosphere.

The National Norms and Standards for the Management of Elephants in South Africa ${ }^{87}$ represent an example of a legal policy that reflects elements of a welfarecentric ethic. These norms and standards were issued in terms of section 9 of the National Environmental Management: Biodiversity Act. ${ }^{88}$ This Act is concerned with 'the management and conservation of biological diversity' and the protection of the ecosystem, including species. ${ }^{89}$ The Elephant Norms and Standards indicate a strong ethical concern for the well-being of individual elephants within the context of concerns for the health of their habitat as well as the well-being of humans. They include the goals of ensuring the long-term survival of elephants within their ecosystem so that they do not disrupt the ecological integrity of such ecosystems, the recognition of their sentience, as well as their ethical and humane management.90 The guiding principles included in the Elephant Norms and Standards affirm the intelligence of elephants, the disruptive force of human beings, as well as the potential threat to the well-being of human beings posed by the close proximity of elephants to people. ${ }^{1}$

The process that led to this policy document is also exemplary of the manner in which FCT may shape the development of legal measures in response to animal suffering or potential suffering. The debate surrounding the resumption of the culling of African elephants in the Kruger National Park in South Africa resulted in a national and international outcry, which awakened the public's compassion for the plight of individual elephants. Subsequently, an extensive consultation process took place between governmental bodies and a wide range of stakeholders, which ultimately led to the declaration of principles as well as norms and standards for the management of elephants, based on the notion of caring 92

\footnotetext{
${ }^{87}$ Government Notice No. 251, Government Gazette, No. 30833, 29 Feb. 2008.

${ }^{88}$ Act 10 of 2004 (Biodiversity Act).

${ }^{89}$ Ibid., s. 2.

90 Ibid., Pt 2.

${ }^{91}$ Ibid., Pt 3.

${ }^{92}$ For a discussion of the process see D. Bilchitz, 'Animal Interests and South African Law: The Elephant in the Room?', in D. Cao \& S. White (eds), Animal Law and Welfare: International Perspectives (Springer, 2016), pp. 131-55, at 148. Views may differ on the manner in which the policy reflects caring, as culling is still recognized as a last resort.
} 


\section{Desired compassion and legal limits}

The injection of compassion in international wildlife law necessitates a policy discourse to determine what is desirable within the limits of the possible.93 It is imperative to acknowledge that, so far, international wildlife law follows a holistic approach to conservation and has scant regard for the welfare of individual animals. Hence, it is important to scan the legal landscape and identify opportunities to introduce a welfarecentric ethic into wildlife law.

An important question that arises is how international wildlife law could accommodate a move towards a welfare-centric ethic. The support by Bowman, Davies and Redgwell for recognition of the concern for animal welfare as a general principle of international law in terms of Article 38(1)(c) of the Vienna Convention on the Law of Treaties (VCLT) 94 is very promising in this regard. ${ }^{95}$ There is cause to be optimistic about the suitability of Article 38(1)(c). General principles allow for the utilization of progressive interpretation in order to respond to modern-day challenges, such as the changing human-animal relationship. ${ }^{6} 6$ General principles could form the basis for the progressive development of new wildlife welfare obligations in international law.97

However, Article 38(1)(c) VCLT remains an ambiguous source of law, and is of a fairly limited scope. 98 This does not mean that animal welfare is not susceptible to recognition under Article 38(1)(c). Voigt's work on the recognition of sustainable development as a general principle of international law may provide helpful insights for this discussion. 99 It is important to remember that state practice is not required for the recognition of general principles. Rather, general principles are recognized if they can be shown to be part of a 'common legal conscience' (opinio juris communis) of states.100 As such, the determination of the recognition of the opinio juris communis may overlap with the determination of the opinio juris of states as a requirement for customary international law in that both entail a determination of (subjective) legal conscience. ${ }^{101}$ However, in the case of general principles, the relevant legal conscience is not restricted to states, but

\footnotetext{
${ }^{93}$ See M.R. Kamminga, 'The Ethics of Climate Politics: Four Modes of Moral Discourse' (2008) 17(4) Environmental Politics, pp. 67392, in relation to the ethics of climate politics; see also J.M. Gustafson, Intersections: Science, Technology and Ethics (Pilgrim Press, 1996).

94 Vienna (Austria), 23 May 1969, in force 27 Jan. 1980, available at: https://treaties.un.org/doc/publication/unts/volume\%201155/volume-1155-i-18232-english.pdf. Bowman, Davies \& Redgwell, n. 23 above, p. 681.

${ }^{95}$ Ibid., pp. 675-82. See also the analysis of Sykes, n. 11 above, pp. 46-7. It is not the intent of the author to repeat in detail the convincing arguments of Bowman, Davies \& Redgwell and Sykes in support of the recognition of animal welfare as a general principle.

${ }^{96}$ M.C. Bassiouni, 'A Functional Approach to General Principles of International Law' (1989/90) 11 Michigan Journal of International Law, pp. 768-818, at 769 .

${ }^{97}$ General principles may be identified from national and/or international sources: Bassiouni, ibid., pp. 768, 772.

${ }^{98}$ The ambiguous nature of general principles of international law has been the source of 'vast amounts of doctrinal debate', which are beyond the scope of this article: see O. Elias \& C. Lim, “"General Principles of Law", "Soft Law" and the Identification of International Law' (1997) 28 Netherlands Yearbook of International Law, pp. 3-49, at 3, 5.

${ }^{99}$ C. Voigt, Sustainable Development as a Principle of International Law (Brill, 2009), pp. 145-88.

${ }^{100}$ Ibid., p. 157.

101 Ibid., p. 159.
} 
includes 'normative requirements ... which introduce a sense of what is right and what is wrong into judicial reasoning'. ${ }^{102}$ This implicates not only the 'state of mind' of state actors as conveyed in their declarations and statements, but also the legal animus expressed by non-governmental organizations (NGOs) and international organizations. ${ }^{103}$

Domestic law and international law each contain various examples of emerging concerns for animal welfare. ${ }^{104}$ Most states have domestic legal regimes that prohibit animal cruelty, and a number of countries have constitutional provisions that recognize animals as sentient beings deserving of legal protection.105 On the international plane, it is evident that international wildlife law is still concerned predominantly with conservation and that animal welfare features in an ancillary manner. Nevertheless, the 1973 Convention on International Trade in Endangered Species of Wild Fauna and Flora (CITES) ${ }^{106}$ contains numerous provisions in relation to animal welfare ${ }^{107}$ Furthermore, international (soft) law documents reflect a concern for animal welfare, 108 and NGOs and international organizations have also expressed an interest in animal welfare law. ${ }^{109}$

The procedural function of the general principle of law concerning animal welfare is that it renders 'national decisions amenable to some form of institutional review while reserving ultimate discretion to governments in respect of concrete application'. ${ }^{110} 110$ The substantive legal significance lies in its form as a 'meta- principle' that is relevant to the interpretation of norms via Article 31(3)(c) VCLT. ${ }^{111}$ Thus, a convergence towards the recognition of animal welfare as a general principle of international law may have a profound impact on the interpretation of international wildlife law treaties - in particular, instruments that address the removal of wildlife (through hunting, killing,

\footnotetext{
102 Ibid.,

103 Ibid., p. 158.

104 R. Wolfrum, 'Sources of International Law', Max Planck Encyclopedia of International Law, para. 39, available at: http://opil.ouplaw.com/view/10.1093/law:epil/9780199231690/law-9780199231690-e1471 ?rskey=wWAIra\&result=2\&prd=EPIL.

${ }^{105}$ For a comprehensive comparative overview of domestic jurisdictions that regulate animal welfare, see Wagman \& Liebman, n. 14 above, pp. 28-47; see also Michel, n. 14 above.

106 N. 15 above.

${ }^{107} \operatorname{Arts} \operatorname{III}(2)(c), \operatorname{III}(4)(b), \operatorname{IV}(2)(c), \operatorname{IV}(5)(b), \operatorname{IV}(6)(b), \operatorname{VI}(2)(b), \operatorname{VII}(7)(c)$ and VIII(3) CITES.

${ }^{108}$ See also Sykes, n. 11 above, p. 22. The World Conservation Strategy states that '[e]very form of life warrants respect independently of its worth to people' and '[p]eople should treat all creatures decently, and protect them from cruelty, avoidable suffering and unnecessary killing': C.J. Barrow, Caring for the Earth: A Strategy for Sustainable Living (International Union for the Conservation of Nature (IUCN), United Nations Environment Programme (UNEP) and World Wide Fund for Nature (WWF), 1991). The Preamble to the Johannesburg Declaration on Sustainable Development (UN Doc. A/CONF.199/20, Johannesburg (South Africa), Sept. 2002, available at: http://www.joburg.org.za/pdfs/johannesburgdeclaration.pdf) strives for a 'humane, equitable, caring global society' and affirms humanity's 'responsibility to one another, to the greater community of life and to our children'.

109 The Universal Declaration on Animal Welfare (UDAW), initially proposed by the World Society for the Protection of Animals (WSPA) in 2000 (available at: https://www.globalanimallaw.org/database/universal.html), and the draft texts of the International Convention for the Protection of Animals (ICPA) and its protocols (available at: https://www.animallaw.info/treaty/internationalconventionprotection-animals) serve as examples.

${ }^{110}$ Bowman, Davies \& Redgwell, n. 23 above, p. 680.

${ }^{111}$ Ibid., p. 681. This provision states that together with the context 'any relevant rules of international law applicable in the relations between the parties' shall be taken into account.
} 
culling or trapping), its transportation, and the management of captive wildlife. ${ }^{112}$ International wildlife instruments that are conservation-oriented will not be able to ignore welfare concerns. The present author, for example, has recently argued ${ }^{113}$ that animal welfare as a general principle of international law may influence the interpretation of the provisions of the International Convention for the Regulation of Whaling (ICRW). ${ }^{114}$ An interpretation of Article V ICRW that takes into account animal welfare by virtue of Article 31(3)(c) VCLT indicates that the killing methods may not be dealt with in isolation from welfare issues. Furthermore, the pursuit of conservation and the orderly development of the whaling industry may not ignore animal welfare concerns, in this instance the 'humanity' of whaling operations.

The interpretative function of animal welfare as a general principle provides for the consideration of (individual) welfare obligations of sentient animals in the context of (holistic) conservation measures. As such, the emergence of animal welfare as a general principle does not appeal to the existence of (subjective) animal rights and does not fall prey to the possibility that those interested in the welfare of animals may be willing 'to sacrifice the authenticity, integrity and complexity of ecosystems to protect the rights, or guard the lives, of animals'. ${ }^{115}$ Sagoff aptly remarks that '[o]nly individuals may have rights, but environmentalists think in terms of protecting collections, systems and communities' and as such 'moral obligations to nature cannot be enlightened ... by appealing to the rights of animals'. Thus, an appeal to animal rights (a 'humanitarian ethic') 'will not provide ... valid foundations for environmental law'. ${ }^{116}$

The possible recognition of animal welfare as a general principle of international law implies that this concept may be plagued by vagueness and indeterminacy as a result of the general and 'unfinished'117 nature of the relevant general principles. ${ }^{118} \mathrm{~A}$ uniform definition of animal welfare is lacking, but the notion of 'humane treatment' or the prevention of unnecessary pain constitutes the nucleus of animal welfare and could constitute the foundation for more developed animal welfare standards. ${ }^{119}$ The unfinished nature of the general principles invites further specification and concretization through treaty law and custom. ${ }^{120}$

\footnotetext{
112 Ibid., pp. 682-97.

${ }^{113}$ Scholtz, n. 33 above.

${ }^{114}$ Washington DC (US), 2 Dec. 1946, in force 10 Nov. 1948, available at: https://iwc.int. A caveat applies. Unfortunately tribunals and courts rarely make use of the interpretative function of general principles and, as such, the utility of general principles remains limited. This is also evident from the decisions of the Permanent Court of International Justice (PCIJ) and the International Court of Justice (ICJ): H.W.A. Thirlway, The Sources of International Law (Oxford University Press, 2014), p. 98.

115 M. Sagoff, 'Animal Liberation and Environmental Ethics: Bad Marriage, Quick Divorce' (1984) 22 Osgoode Hall Law Journal, pp. 297-307, at 304 (emphasis in original).

116 Ibid., p. 305.

${ }_{117}$ M. Bos, 'The Recognized Manifestation of International Law' (1977) 20 German Yearbook of International Law, pp. 9-76, at 42.

118 As Koskenniemi aptly remarks, 'greater coverage of State practice through general principles seems to be achieved only at the cost of the critical content of those principles': M. Koskenniemi, Sources of International Law (Ashgate, 2000), p. 398.

119 Gillespie, n. 38 above, p. 6. The deliberations of the International Whaling Commission (IWC) in relation to humane treatment are informative. The IWC does not work with an agreed definition of welfare. However, other expert bodies and intergovernmental organizations have established agreed definitions in order to aid intersessional deliberations on welfare issues. In this regard, welfare is
} 
The gradual recognition of the importance of animal welfare in international wildlife law exhibits some similarities with the development of sustainable development in international environmental (conservation) law. Sustainable development was coined in response to the need for development that takes cognizance of ecological boundaries. The innovative use of 'soft law'121 declarations - such as the 1972 Stockholm Declaration on the Human Environment ${ }^{122}$ and the 1992 Rio Declaration on Environment and Development ${ }^{123}$ - spawned subsequent concrete treaties and resulted in the entrenchment of sustainable development as the leitmotif of international environmental law. ${ }^{124}$ Hence, an international impetus is required to induce the progressive development of animal welfare protection, in particular in international wildlife law, in order to ensure that animal welfare is not merely viewed as 'peripheral to environmental concerns within the global goal of sustainable development'. ${ }^{125}$

The proposed Universal Declaration on Animal Welfare (UDAW) ${ }^{126}$ may provide an opportunity for the further development of animal welfare law. The UDAW, which was proposed initially by a group of animal welfare organizations, ${ }^{127}$ contains broad nonbinding principles on animal welfare which are intended to be adopted as a resolution of the United Nations (UN) General Assembly. The UDAW also applies to wild animals. ${ }^{128}$ The Preamble recognizes the coexistence and interdependence of human beings and animals. The UDAW proposes that all appropriate steps be taken by Member States to prevent animal cruelty and to reduce suffering. ${ }^{129}$ However, the principles that inform the UDAW do not provide clear obligations and guidance in relation to animal welfare issues. This at first seems to diminish the quality of the declaration, but it also offers several advantages, such as easier adoption of the document as a resolution. Further, the

considered 'to be the health of an animal, encompassing both its physical and psychological state. An animal in a good state of welfare (as indicated by scientific evidence) would be free from pain, fear, and distress and be healthy, well nourished, and able to express innate behavior': Report of the IWC 65 (2014), IWC/65/WKM\&AWI05 Rev2, WKM\&AWI Agenda item 6.3, Addressing Welfare

within Q20 the IWC: Intersessional Working Group on Welfare, Summary Recommendations, available at: https://archive.iwc.int/pages/search.php? search=\%21 collection99\&k=.

${ }^{120}$ General principles of international law may be resorted to in order to identify opinio juris and as such may provide orientation to customary international law: see the Separate Opinion of Judge Cançado Trindade in the ICJ case, Pulp Mills on the River Uruguay (Argentina v. Uruguay), Judgment of 20 Apr. 2010, ICJ Reports (2010), p. 204.

${ }^{121}$ G. Palmer, 'New Ways to Make International Environmental Law' (1992) 86(2) American Journal of International Law, pp. 259-83, at 259.

122 Adopted by the UN Conference on the Human Environment, Stockholm (Sweden), 5-16 June 1972, available at: http://www.unep.org/documents.multilingual/default.asp?documentid=97\&articleid=1503.

123 Adopted by the UN Conference on Environment and Development, Rio de Janeiro (Brazil), 3-14 June 1992 , UN Doc. A/CONF.151/26/Rev.1 (Vol. I), 14 June 1992, available at: http://www.un.org/documents/ga/conf151/aconf15126-1annex1.htm.

${ }^{124}$ W. Scholtz, 'Legal Protection of the Environment', in H.A. Strydom (ed.), International Law (Oxford University Press, 2015), pp. $504-44$, at 511.

${ }^{125}$ Birnie, Boyle \& Redgwell, n. 30 above, p. 600.

${ }^{126}$ N. 109 above.

127 This group included World Animal Protection, which was formerly the World Society for the Protection of Animals. The proposed agreement has been revised several times.

${ }^{128}$ Draft UDAW (2011), n. 109 above, Art. V.

${ }^{129}$ Ibid., Art. VI. 
UDAW (in the form of a resolution) may create awareness of the issue of animal welfare at the UN level and therefore serve as a catalyst for further legal action in this regard. This is similar to the manner in which sustainable development entered the legal conscience of states. An important aspect of the UDAW is that it sets the parameters for the content of animal welfare as well as very broad principles that may guide future action. ${ }^{130}$

A normative concretization may subsequently occur through other sources of international law. In this regard, the international environmental law approach that favours framework conventions and more detailed protocols may be useful. ${ }^{131}$ The Committee for the Convention for the Protection of Animals proposed an International Convention for the Protection of Animals (ICPA) and protocols in 1988,132 which could serve as a model approach for the progressive promotion of animal welfare. The proposed umbrella treaty aims to deal with a comprehensive range of animal welfare-related issues and applies also to wildlife welfare. The instrument recognizes the links between welfare and conservation, as the Preamble states that the 'misuse and wastage of animals impairs the conservation of the environment as well as cultural and economic development'. ${ }^{133}$ The Preamble also recognizes the need for international standards in response to the international concern over animal cruelty and is grounded on the conviction that mankind has obligations towards animals. It is based on the principles of interdependency between human beings and animals in an interdependent ecosystem and the recognition that life has intrinsic value.134 The instrument provides protection for animals according to specified categories: wildlife, captive wildlife, domestic animals, companion animals, commercial animals, and animals used in scientific research. ${ }^{135}$ The ICPA explicitly affirms the link between the conservation of habitat and the welfare of wildlife, as Article 4 obliges Contracting Parties to take 'appropriate steps to use those scientific management practices which result in the least suffering to wildlife and shall conserve wildlife habitat where possible'. Article 3 obliges parties to reduce the suffering of wildlife in circumstances of their being killed or captured and to 'minimize to the greatest extent possible indiscriminate harm to non-target animals or the environment'. Under the 'General Undertakings' embodied in Article 10, parties are required to take all appropriate measures to 'prevent the subjection of animals to cruelty and unnecessary suffering and to conserve the natural habitat of wildlife'. ${ }^{136}$ This provision introduces some form of shared responsibility between parties as it refers to

\footnotetext{
${ }^{130}$ Ibid., Art. II states that 'animal welfare includes animal health and encompasses both the physical and psychological state of the animal. The welfare of an animal can be described as good or high if the individual is fit, healthy, free from suffering and in a positive state of wellbeing'.

${ }^{131}$ D. Favre, 'An International Treaty for Animal Welfare' (2011-12) 18 Animal Law, pp. 237-80. Ozone depletion and climate change, as well as biodiversity regimes, are illustrative of this approach: Scholtz, n. 124 above, pp. 523-36.

132 ICPA, n. 109 above.

133 This statement may be criticized for its anthropocentricity. Animal rights advocates may be critical of the fact that it does not subscribe to abolition but is based rather on the socio-economic realities of the advantages that people gain from the utilization of animals.

${ }^{134}$ ICPA, n. 109 above, Art. 1.

${ }^{135}$ Ibid., Art. 2 contains the various definitions and Arts 3-9 deal with the separate categories.

${ }^{136}$ Ibid., Art. 10(1).
} 
individual and joint responsibility. The ICPA envisages the adoption of additional protocols. ${ }^{137}$ Correspondingly, the Companion Animal Protocol, the Protocol for the Care of Exhibited Wildlife, the Protocol for the Taking of Wild Animals and the Protocol for the International Transportation of Animals have also been proposed. ${ }^{138}$

Lastly, normative capture may also occur in the future through customary international law. Claims to the customary international law status of animal welfare are premature at this stage and would be contentious, but may be explored in future. The recognition of animal welfare as a general principle of international law could contribute to the determination of animal welfare as part of customary international law as opinio juris communis may overlap with the determination of opinio juris of states as a requirement for customary international law, in that both entail a determination of a (subjective) legal conscience. Furthermore, the adoption of the UDAW as a resolution of the UN General Assembly may also be indicative of the emerging existence of opinio juris.

\section{Compassionate conservation: towards wildlife protection}

The proposed injection of ethics into wildlife law may have a profound impact on international wildlife law, which is concerned predominantly with conservation. The possible emergence of animal welfare as a general principle of international law and the potential progressive development of international wildlife welfare through subsequent international instruments and future customary international law may result in an incremental reconciliation of animal welfare and conservation in international wildlife law. This reconciliation could ultimately foster a move towards protection in certain situations rather than mere conservation. 'Protection' and 'conservation' were initially interchangeable concepts, as was indicated in earlier treaties such as the International Convention for the Protection of Birds of 1950.139 These concepts, however, came to have distinct meanings. Van Heijnsbergen notes that protection often expresses 'a sometimes incidental protective action to prevent damage to the object to be protected' and, furthermore, protection may also 'have an ethical connotation, in the sense that it implies protection of the weak against the strong' ${ }^{140}$ CITES, which contains several references to conservation and protection, offers an example of the broader scope of protection. For example, Article XI(7) provides for a 'body or agency technically qualified in protection, conservation or management of wild fauna and flora' to participate in the meetings of the Conference of the Parties. ${ }^{141}$ Bowman argues convincingly that, in terms of treaty interpretation, the principle of effectiveness implies that the term 'protection' is not synonymous with 'conservation',

\footnotetext{
${ }^{137}$ Ibid., Arts 10(2) and 12.

${ }^{138}$ Available at: https://www.animallaw.info/treaty/international-convention-protection-animals.

139 Paris (France), 18 Oct. 1950, in force 17 Jan. 1963, available at: http://www.ecolex.org/details/treaty/international-convention-forthe-protection-of-birds-tre-000066. See P. van Heijnsbergen, International Legal Protection of Wild Fauna and Flora (IOS Press, 1997), p. 43.

${ }^{140}$ Van Heijnsbergen, ibid.

${ }^{141}$ The Preamble together with Arts II(2)(b), IV(2)(b), V(2)(a), XII, XIV, and XVI of CITES refer to protection.
} 
but that it also includes concern for the welfare of individual animals and not merely the conservation of species. ${ }^{142}$ The argument that the scope of protection is distinct from conservation follows from the use of the term in CITES. ${ }^{143}$ The text also contains a few self-standing references to protection, which relate to the review of the implementation of progress made towards the conservation of Appendices I, II and III species $^{144}$ as well Appendices I and II amendments. ${ }^{145}$ It follows that protection seems to embrace both conservation and welfare objectives.

A caveat applies. The meaning of protection in CITES relates specifically to the provisions of the instrument and does not result per se in a re-interpretation of 'conservation' in other treaties. It does, however, affirm that the emergence of animal welfare in international wildlife law may result in a convergence between conservation and welfare - in particular, in relation to instruments that deal with the removal and transportation of wildlife and the management of captive wildlife. The consideration of welfare concerns in conservation treaties might result in the protection of animals rather than mere conservation. The proposed move towards protection of wildlife could foster a rapprochement between wildlife law and ethics, which affirms the recognition of the moral worth of individual sentient beings for their own sake as well as the importance of non-conscious natural entities, through the intertwined relationship between wildlife, humans and habitat. As such, a stronger focus on protection may confirm a gradual departure from the shackles of anthropocentrism towards a welfare-centric ethic that is cognizant of the important interplay between the well-being of individuals and the health of habitat.

\section{Conclusion}

The proposals in this article advocate the injection of ethics through compassion into international wildlife law, in order to ensure that law is responsive to the recognized sentience and moral worth of wildlife. Conservation without welfare is overtly anthropocentric and ultimately cruel. The reconciliation of conservation and welfare may result in the furtherance of animal protection beyond mere conservation. Animal protection has an ethical connotation as it also entails the protection of animal welfare against human action. As such, it represents a more ethical approach to the humanenvironment interaction, which has the potential to heal the wounds caused by the divorce between ethics and our attitude towards wildlife and the environment. The time is ripe to reconcile conservation and animal welfare in order to ensure that international wildlife law does not merely conserve for man's sake, but rather protects wildlife with compassion and caring.

\footnotetext{
142 Bowman, n. 15 above, p. 11.

${ }^{143}$ Arts III and IV CITES deal with the conditions for granting export permits for Appendix I and II species, which stipulate conditions such as compliance with the laws of the relevant state for the protection of fauna and flora. The subsequent provisions in Articles III and IV deal with minimizing the risk of injury, damage to health or cruel treatment in relation to shipping and preparing.

${ }^{144}$ Art. XI CITES.

${ }^{145}$ Art. XV(2)(b) CITES.
} 